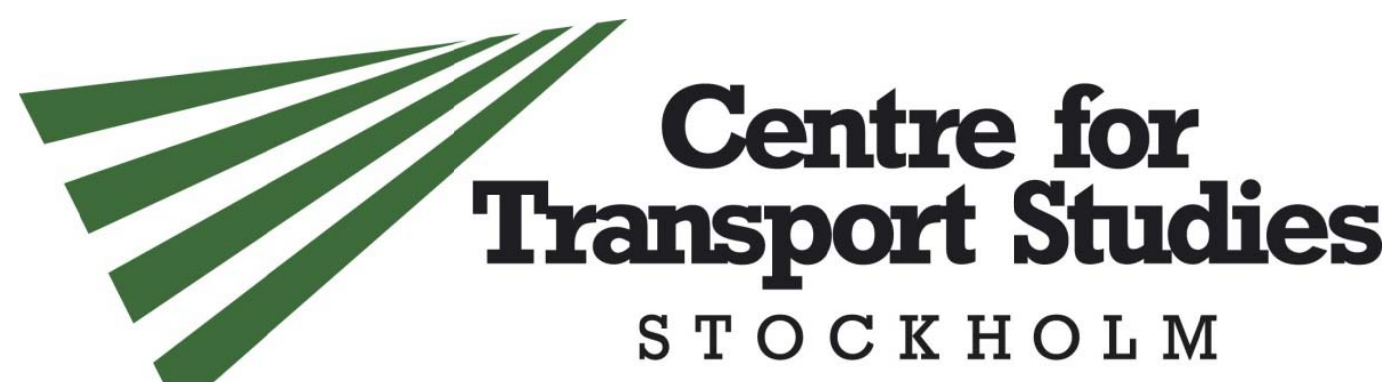

\title{
The Influence of Individuals’ Environmental Attitudes and Urban Design Features on Their Travel Patterns in Siustainable Neighborhoods in the UK
}

\author{
Yusak O. Susilo - Royal Institute of Technology (KTH) \\ Katie Williams - University of the West of England (UWE), Bristol, UK \\ Morag Lindsay - Oxford Brookes University, UK \\ Carol Dair - Oxford Brookes University, UK
}

CTS Working Paper 2012: 1

\begin{abstract}
This paper explores the influence of individuals' environmental attitudes and urban design features on travel behavior, including mode choice. It uses data from residents of 13 new neighborhood UK developments designed to support sustainable travel. It is found that almost all respondents were concerned about environmental issues, but their views did not necessarily 'match' their travel behavior. Individuals' environmental concerns only had a strong relationship with walking within and near their neighborhood, but not with cycling or public transport use. Residents' car availability reduced public transport trips, walking and cycling. The influence of urban design features on travel behaviors was mixed, higher incidences of walking in denser, mixed and more permeable developments were not found and nor did residents own fewer cars than the population as a whole. Residents did, however, make more sustainable commuting trips than the population in general. Sustainable modes of travel were related to urban design features including secured bike storage, high connectivity of the neighborhoods to the nearby area, natural surveillance, high quality public realm and traffic calming. Likewise the provision of facilities within and nearby the development encouraged high levels of walking.
\end{abstract}

Keywords: Sustainable urban design, Travel patterns, Attitudes and beliefs, Sustainable travel modes

JEL Codes: O18, O21, O44, R21, R,28, R31, R42, R58, Z10 



\title{
The influence of individuals' environmental attitudes and urban design features on their travel patterns in sustainable neighborhoods in the UK
}

\author{
Yusak O. Susilo ${ }^{\mathrm{a}, *}$, Katie Williams ${ }^{\mathrm{b}}$, Morag Lindsay ${ }^{\mathrm{c}}$, Carol Dair $^{\mathrm{c}}$ \\ ${ }^{a}$ Centre for Transport Studies, Department of Transport Science, KTH Royal Institute of Technology, Teknikringen 10, 10044 Stockholm, Sweden \\ ${ }^{\mathrm{b}}$ Centre for Sustainable Planning and Environments, Department of Planning and Architecture, University of the West of England, Frenchay Campus, \\ Bristol BS16 1QY, UK \\ ${ }^{\mathrm{c}}$ Oxford Institute for Sustainable Development, Oxford Brookes University, Headington, Oxford OX3 OBP, UK
}

\section{A R T I C L E I N F O}

\section{Keywords:}

Sustainable urban design

Travel patterns

Attitudes and beliefs

Sustainable travel modes

\begin{abstract}
A B S T R A C T
This paper explores the influence of individuals' environmental attitudes and urban design features on travel behavior, including mode choice. It uses data from residents of 13 new neighborhood UK developments designed to support sustainable travel. It is found that almost all respondents were concerned about environmental issues, but their views did not necessarily 'match' their travel behavior. Individuals' environmental concerns only had a strong relationship with walking within and near their neighborhood, but not with cycling or public transport use. Residents' car availability reduced public transport trips, walking and cycling. The influence of urban design features on travel behaviors was mixed, higher incidences of walking in denser, mixed and more permeable developments were not found and nor did residents own fewer cars than the population as a whole. Residents did, however, make more sustainable commuting trips than the population in general. Sustainable modes of travel were related to urban design features including secured bike storage, high connectivity of the neighborhoods to the nearby area, natural surveillance, high quality public realm and traffic calming. Likewise the provision of facilities within and nearby the development encouraged high levels of walking.
\end{abstract}

(c) 2011 Elsevier Ltd. All rights reserved.

\section{Introduction}

There is a belief that urban environments that are designed to particular sustainable design principles may encourage people to reduce their car use and choose more sustainable modes for their travel activities. There is a general consensus within planning and urban design policy and guidance that the 'right' urban design can stimulate the use of public transport, resulting in a reduction in car use. There is a vast amount of empirical evidence suggesting that car travel is lower in traditional-style neighborhoods characterized by higher densities and a mixture of land uses; accessibility is often better in this type of neighborhood with more pedestrian-orientated design features which encourage greater use of non-motorized modes.

Based on previous studies, and to promote sustainable and less car dependent developments, the UK government has published various policy documents seeking to encourage higher density, mixed-use developments; discourage out-of-town developments; and encourage the development of new pedestrian and bicycle infrastructure, and improved access to public transport. It is hoped that these strategies will make places more sustainable, by bringing residents closer to their destinations,

\footnotetext{
* Corresponding author.

E-mail addresses: yusak.susilo@abe.kth.se, yosusilo@gmail.com (Y.O. Susilo).
} 
reducing the need to travel, providing viable alternatives to car use and making it safer and easier for individuals to access jobs and services by energy efficient modes such as walking and cycling.

As a response to these policies and others focusing on sustainable planning many 'sustainable' residential schemes have been built across the UK (Williams and Dair, 2007). These schemes contain a number of 'sustainable' urban design features, e.g. they are higher density with more permeable layouts than previous developer norms, they may have infrastructure to support walking and cycling and include water and energy efficient elements.

This paper tests whether places that are designed to support sustainable travel actually encourage residents to travel by more sustainable modes: it considers which urban design features are associated with different modal choices. It also investigates the impact of residents' beliefs on their travel modes, in combination with urban form features. It uses data that have been collected from 659 residents from 13 relatively new developments with a number of sustainability features in the UK.

\section{Sustainable urban form and sustainable behavior}

The influence of urban form on specific indices of the activities and behavior of travellers (e.g. number of trips and travel time expenditure) has been extensively examined. A general consensus is that the denser the urban structure, particularly when locating a mix of uses in close proximity to each other, the less dependence there is on the car. Such urban forms result in densities that are high enough to support public transport services and can encourage greater levels of walking and cycling (Hickman and Banister, 2005).

At the master planning scale it is argued that high-density developments within existing built up areas can enable most people to live near amenities, facilities and employment and thus reduce the need to travel (Department of the Environment Transport and the Regions, 2000). Mixed-use developments are advocated for similar reasons (Barton et al., 2003). In addition, the appropriate design of the movement framework is seen as the best way to ensure that car use is limited (Department of the Environment Transport and the Regions, 1998). This means transport networks that are well integrated with the surrounding area, have dedicated, convenient, direct routes for pedestrians and cyclists, and are linked in a grid or deformed grid pattern, rather than a cul-de-sac configuration, are advocated (Williams and Dair, 2007). They also need to be able to accommodate public transport and offer direct routes to interchanges (Department of the Environment Transport and the Regions and the Commission for Architecture and the Built Environment, 2000).

Whilst there is evidence that certain physical forms can have a positive impact on promoting more sustainable towns and cities, some studies have questioned this. For example, some have argued that denser environments alone do not necessarily lead to the desired effects of reducing car use and promoting walking, cycling and public transport use, and raise concern over the 'compact city's' contribution to wider sustainable travel patterns on both regional and intra-regional travel. Williams et al. (2000), for example, highlight that other urban forms such as multi-centered or corridor developments may also have significant sustainable transport benefits.

The variability in effect of urban form may be explained, partially, by differences in cultural, attitudinal and individual socio-demographic factors. Susilo and Dijst (2009), Susilo and Waygood (2012), and others for example, have found that although land use characteristics have some significance in explaining travel behavior, individual attitudes are often more strongly associated with travel behavior than land use policies that promote higher densities. It is evident that urban form policies may not have a material effect on travel demand unless individuals' attitudes are also changed.

\section{Data and study areas}

We use a dataset derived from 659 completed questionnaires from residents of 13 developments with some sustainable features in the UK. The questionnaires included questions on individual activity-travel information, such as travel mode choice, trip frequency, and activity locations. They also recorded views about environment and sustainable behaviors and also some socio-demographic information.

The questionnaires were distributed in the 13 residential schemes in the UK shown in Fig. 1. The developments were chosen to give a spread and range of physical features to be examined. Each development is either solely residential or predominantly housing, with a range of other uses such as shops and schools. The developments chosen have been occupied for a minimum of 2 years, to enable behavior patterns to 'settle'.

The physical features of the developments were assessed using a sustainability checklist that contains all the elements that could support sustainable behavior and, potentially, be provided in a scheme. Each development has unique features (Williams et al., 2009), and all the built environment characteristics which are claimed in theory or policy to have an impact on travel are included in the analysis.

The travel information is collected using self-reported questionnaires. Respondents reported their individual travel mode choice for different travel purposes based on whether they were within the development area, nearby, or further away, and the frequency of visits. 'Within the development area' means the activity locations are within the neighborhood, whilst'nearby' means that the activities are up to $1 \mathrm{~km}$ from the neighborhood and 'outside' means the activity is located beyond a $1 \mathrm{~km}$ boundary. For some case studies the 'development area' is the whole new neighborhood, for others it is a specific area within a larger development. 




Fig. 1. The case study locations. Source: Williams et al. (2009).

Overall, the sample profile is similar to national averages for most key characteristics, such as household type and size, age, and the way in which the homes are owned, except that two of the 13 neighborhoods are occupied wholly by tenants of registered social landlords (RSLs). As would be expected, people in the sample have lived in their homes for far shorter a time than average: $40 \%$ had lived in the schemes for less than 2 years. This may affect some behaviors that take time to develop. There is also an over-representation of higher social classes in the sample; $24 \%$ higher managerial and professional, compared with a national average of $13 \%$; and $38 \%$ lower managerial and professional, compared with $23 \%$ nationally.

\section{Travel patterns in sustainable neighborhoods}

\subsection{Travel mode and activity location}

The survey results show that, as expected, there is a relationship between activity location and individual travel choice. The percentage of walking as the travellers' main mode decreased when they accessed activities further away from their homes whilst the percentage of car usage increased.

Two-thirds of the trips to the activities within the development were on foot. However, when accessing the locations outside the nearby area, the proportion of walk tripsis reduced to $8 \%$. Car and public transport trips increase threefold (from $6 \%$ and $24 \%$ to $19 \%$ and $72 \%$ ). Bicycles are used mostly when residents access locations near their developments although only $5 \%$ of respondents travelled by bicycle.

\subsection{Use of locally provided activities}

Providing activities nearby does not automatically encourage all residents to do their activities locally; $61.9 \%$ and $71.3 \%$ of residents visited their local shops and outdoor locations. The figure is much lower for worship and indoor leisure activities (19.3\% and $20.5 \%$ ), but this may be explained by the specific nature of facilities provided. Even when local shops were available, still $90 \%$ of the residents travelled up to $1 \mathrm{~km}$ from the boundary of the development to do their regular shopping, and $60 \%$ travelled beyond this boundary. This is in-line with Susilo et al. (2011) who found that many people only use their local shops as a 'top-up', and not for their main shopping. Clearly, the choice of shopping locations is complex, as many people shop as a leisure activity, and are influenced by the range of retail outlets and the quality of the shopping environment (Handy and Clifton, 2001).

\subsection{Car ownership and household structure}

The mode choice also depends on car availability and respondents' other constraints. The descriptive analysis shows that walking is hardly influenced by car ownership in reaching locations within the development, whilst the use of public transport is influenced by private car availability. Once the respondent has one or more cars, public transport use drops significantly, regardless of the distance of activity locations.

The analysis also shows that household structure has a significant influence on mode choice behavior (Fig. 2). The presence of dependent children did not predicate a preference for private car use as the main travel mode. In reaching locations 
(a) In reaching the activity within the development area

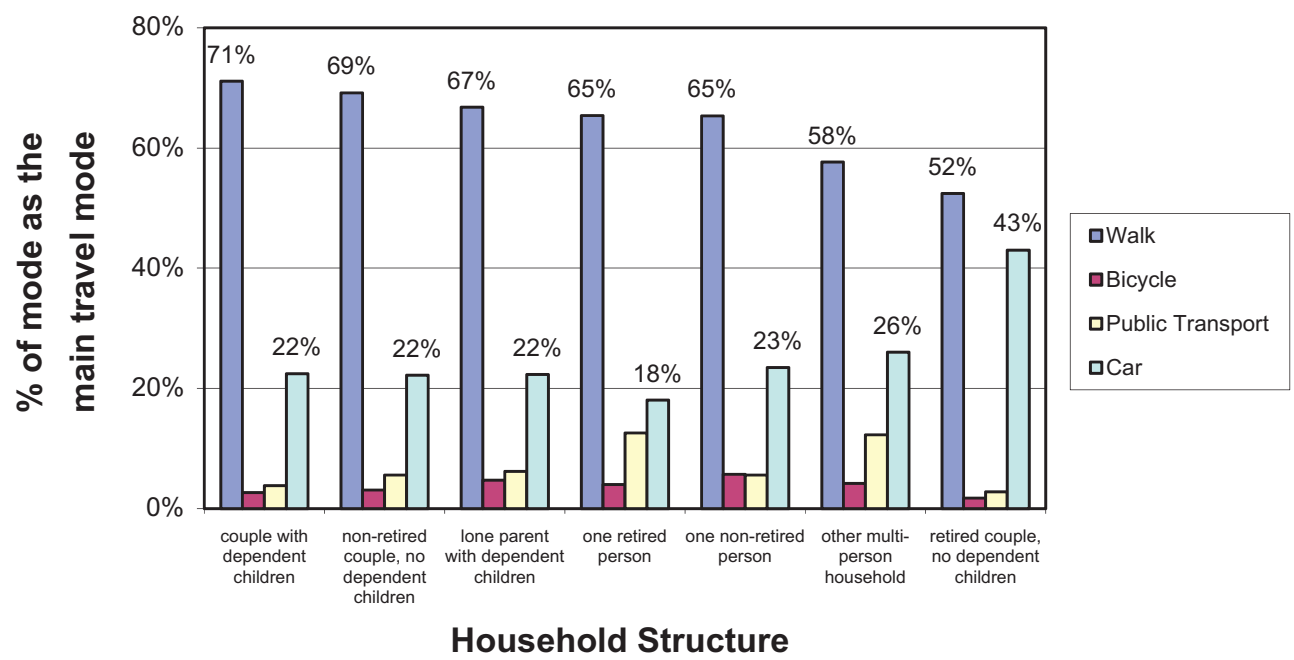

(b) In reaching the activity nearby the development area

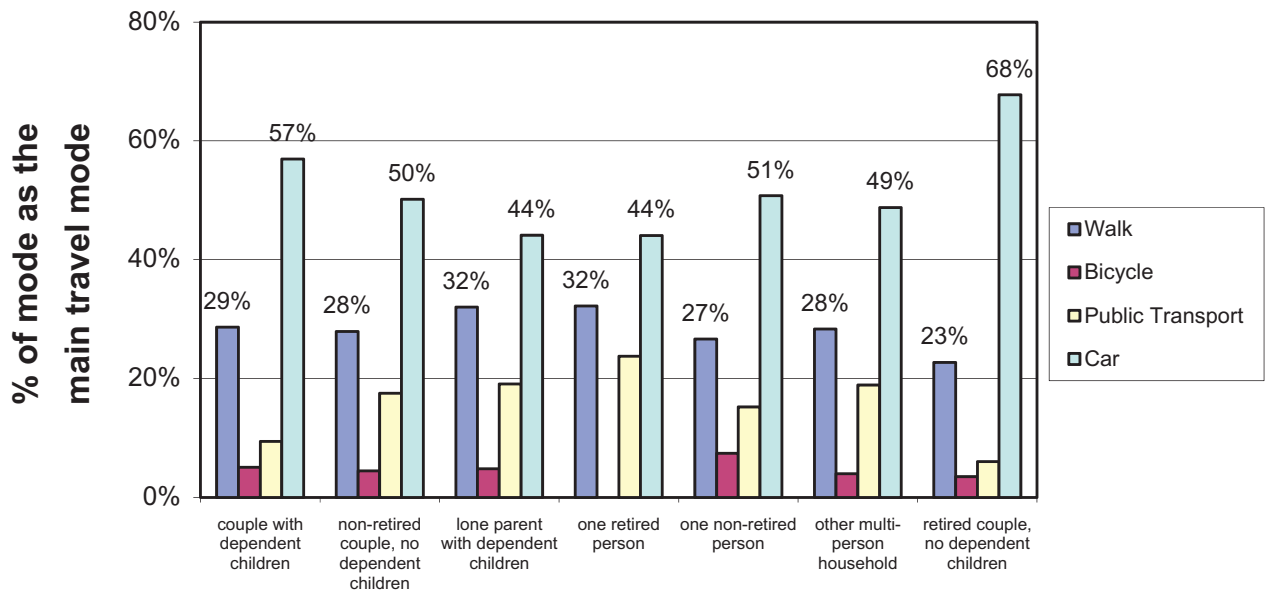

Household Structure

(c) In reaching the activity outside the nearby area of the respondents' home

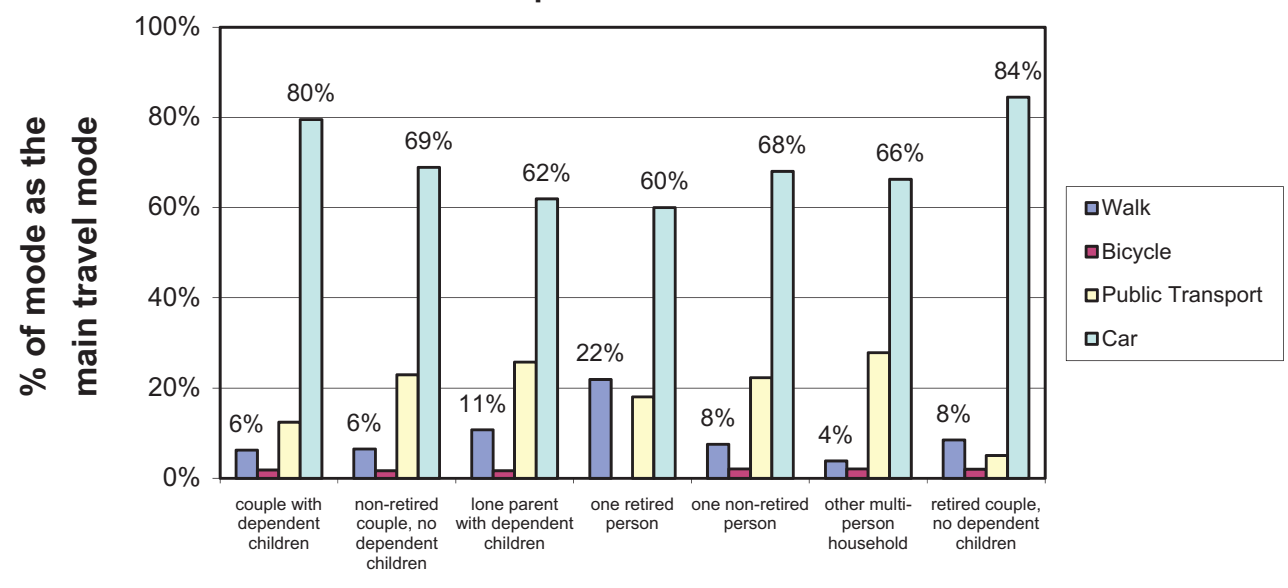

Household Structure

Fig. 2. Mode choice based on household structure and relative activity locations.

that are within a development, only $22 \%$ of parents with children use a car. Forty-three percent of retired couples, however, use a private car to do similar trips. These percentages increase inline with the distance of the activity from home. The percentage of parents with children who use private cars increased to $57-80 \%$ in reaching activities nearby and outside the 


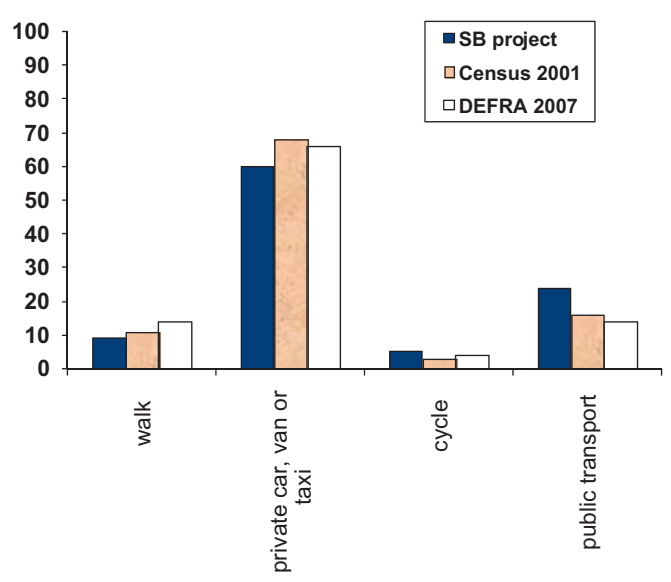

(a) Mode of Travel to Work recorded in the SB, Census and DEFRA Surveys

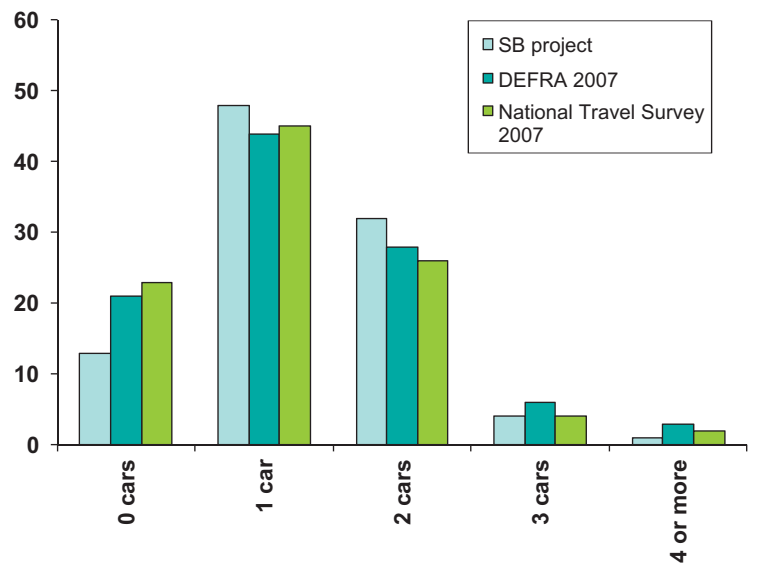

(b) Number of Cars owned/available recorded in the SB, National Travel and DEFRA Surveys

Note: the SB data is that used in the paper

Fig. 3. Car ownership and the commute mode in 'sustainable' neighborhoods compared to National statistics and other studies.

development, respectively. But still, this is lower than retired couples. This graph highlights a trend of motorization among elderly people, who are an increasingly large proportion of the population.

\subsection{Sustainable neighborhoods and sustainable travel}

Although numerous claims are made about the travel impacts of sustainable neighborhoods, it is very difficult to make comparisons because local context is so critical. Below is an analysis of travel to main place of work. Clearly this does not cover travel for non-work uses, nor does it address frequency. Nevertheless it is the most readily comparable measure with wider data sets and is therefore useful.

Fig. 3 shows data from the study of sustainable behaviors (SB), compared with that from other national surveys on commuting behavior. Although this is a rather crude comparison, as slightly varying dates and populations are included, it indicates that fewer people walk to work (9\%) compared with national surveys. This is at odds with the theory and policy advice on sustainable housing, and mixed use schemes, but possibly explained by the more peripheral locations of these developments and the relative distance from a variety of employment opportunities. Fewer people drive to work than national averages (60\% compared with $68 \%$ nationally), which could be seen as a positive outcome. Cycling and public transport use are also higher than the national comparisons, signifying perhaps some success in encouraging cycling and integrating public transport facilities.

Whilst we may expect residents will own fewer cars than the population as a whole, this is not the case. The sample had the lowest percentage of car-free households in any of the comparable national surveys (13\% compared with $32 \%$ in the CORE survey, a survey carried out in a sample of UK cities, for example). The respondents also had the highest percentages owning one and two cars.

These data must be seen in the context of the caveat that the sustainable developments studied have higher proportions of people with higher socio-economic status than the population as a whole, and that some of the developments are in more suburban locations. Hence, these trends may be influenced by socio-demographic and locational factors.

\section{Attitudes and travel patterns}

A $k$-cluster analysis is employed to further explore the relationships between individual and built environment factors and environmental beliefs on travel patterns. The analysis is based on residents' travel patterns, with the 659 individuals grouped into five clusters as (Table 1). The numbers in clusters 1 and 5 are small, but statistically distinct, so have been retained. The clusters have the following characteristics:

1. Group 1 ( $5 \%$ of respondents) - dominated by individuals who moved to, and live in, the development to have better accessibility. They are aware of sustainable development issues and have environmental concerns. They hardly use their car to access locations within and near their development. They believe everybody needs to change their behavior to sustain the environment, including themselves. 
Table 1

Clustering the respondents based on their travel patterns.

\begin{tabular}{|c|c|c|c|c|}
\hline Cluster $1(N=32)$ & Cluster $2(N=87)$ & Cluster $3(N=232)$ & Cluster $4(N=304)$ & Cluster $5(N=2)$ \\
\hline $\begin{array}{l}\text { Mostly walk within the } \\
\text { neighborhood and } \\
\text { combine it with cycling } \\
\text { when going to locations } \\
\text { nearby the } \\
\text { neighborhood. To go } \\
\text { outside the } \\
\text { development area, he/ } \\
\text { she will use private car } \\
\text { (with significant } \\
\text { proportion of bicycle) }\end{array}$ & $\begin{array}{l}\text { High proportion of walking } \\
\text { within the neighborhood } \\
\text { and highly dependent on } \\
\text { public transport to reach } \\
\text { locations nearby and } \\
\text { outside the development } \\
\text { area (combined with small } \\
\text { number of cycling trips) }\end{array}$ & $\begin{array}{l}\text { Mix walking with car trips: } \\
72 \% / 20 \% \text { proportion for } \\
\text { within neighborhood trips; } \\
44 \% / 42 \% \text { proportion for } \\
\text { nearby trips; } 12 \% / 70 \% \\
\text { proportion for trips outside } \\
\text { the development Have the } \\
\text { fewest daily trips }\end{array}$ & $\begin{array}{l}36 \% \text { trips within the } \\
\text { neighborhood are by car. } \\
\text { Highly dependent on the } \\
\text { car for trips nearby and } \\
\text { outside the development } \\
\text { area }\end{array}$ & $\begin{array}{l}\text { Always on-foot or using } \\
\text { bicycle in most of their } \\
\text { trips. Have the highest } \\
\text { number of (on-foot) trips }\end{array}$ \\
\hline $\begin{array}{l}\text { Majority lived at the } \\
\text { current location for less } \\
\text { than } 2 \text { years Moved to } \\
\text { the current location for } \\
\text { the size of the house, } \\
\text { good access to work and } \\
\text { city center. Some of } \\
\text { them (22\%) think that } \\
\text { they do not need to have } \\
\text { a car }\end{array}$ & $\begin{array}{l}\text { Majority lived at the } \\
\text { current location for less } \\
\text { than } 2 \text { years Moved to the } \\
\text { current location for its } \\
\text { convenient access to public } \\
\text { transport. Have the lowest } \\
\text { car ownership level and felt } \\
\text { no need to have one since } \\
\text { they have good public } \\
\text { transport and/or it is just } \\
\text { too expensive }\end{array}$ & $\begin{array}{l}\text { Majority have lived at the } \\
\text { current location for more } \\
\text { than } 2 \text { years. Moved to the } \\
\text { current location for the size } \\
\text { of the house and car park } \\
\text { availability } 50 \% \text { of them } \\
\text { would be encouraged to } \\
\text { walk and cycling more by } \\
\text { good frequency of public } \\
\text { transport service. One third } \\
\text { of them would be } \\
\text { encouraged to do more } \\
\text { walking and cycling by } \\
\text { convenient and well lit and } \\
\text { more direct pedestrian } \\
\text { routes and closer bus stops }\end{array}$ & $\begin{array}{l}\text { Majority have lived at the } \\
\text { current location for more } \\
\text { than } 2 \text { years Moved to the } \\
\text { current location for the size } \\
\text { of the house and car park } \\
\text { availability Have the } \\
\text { highest car ownership level }\end{array}$ & $\begin{array}{l}\text { Lived at the current } \\
\text { location for less than } \\
2 \text { years. They would be } \\
\text { encouraged to do more } \\
\text { walking and cycling by } \\
\text { amore frequent public } \\
\text { transport service and more } \\
\text { people walking }\end{array}$ \\
\hline $\begin{array}{l}\text { The majority would be } \\
\text { encouraged to walk and } \\
\text { cycle more by well lit } \\
\text { and convenient } \\
\text { pedestrian and cycling } \\
\text { routes and more } \\
\text { secured bicycle storage } \\
\text { Almost half of them } \\
\text { (47\%) are between } 31 \\
\text { and } 40 \text { years old. High } \\
\text { proportion of them are } \\
\text { from Waterways }\end{array}$ & $\begin{array}{l}\text { The majority would be } \\
\text { encouraged to walk and } \\
\text { cycle more by convenient } \\
\text { pedestrian routes, good } \\
\text { public transport frequency } \\
\text { and closer location of bus } \\
\text { stops. } 40 \% \text { of them are less } \\
\text { than } 30 \text { years old. High } \\
\text { proportion of them is from } \\
\text { Greenwich Millennium } \\
\text { Village }\end{array}$ & $\begin{array}{l}54 \% \text { of them are more than } \\
40 \text { years old }\end{array}$ & $\begin{array}{l}\text { One third would be } \\
\text { encouraged to do more } \\
\text { walking and cycling by } \\
\text { convenient and well lit and } \\
\text { more direct pedestrian } \\
\text { routes and closer locations } \\
\text { of bus stops }\end{array}$ & \\
\hline $\begin{array}{l}\text { Almost all of them have } \\
\text { heard of "sustainable } \\
\text { development" and agree } \\
\text { that other people need } \\
\text { to change as well as } \\
\text { themselves }\end{array}$ & $\begin{array}{l}\text { Two thirds have heard the } \\
\text { term "sustainable } \\
\text { development" and think } \\
\text { they need to change. But } \\
\text { almost all of them agree } \\
\text { that other people need to } \\
\text { change }\end{array}$ & $\begin{array}{l}\text { Two thirds have heard of } \\
\text { "sustainable } \\
\text { development". Just over } \\
\text { half ( } 57 \%) \text { think they need } \\
\text { to change their behavior. } \\
\text { But almost all of them } \\
\text { agree that other people } \\
\text { need to change }\end{array}$ & $\begin{array}{l}\text { Two thirds have heard of } \\
\text { "sustainable development" } \\
\text { and think they need to } \\
\text { change. Almost all agree } \\
\text { that other people need to } \\
\text { change }\end{array}$ & $\begin{array}{l}\text { They have never heard of } \\
\text { "sustainable development" } \\
\text { but think that both } \\
\text { themselves and other } \\
\text { people need to change }\end{array}$ \\
\hline
\end{tabular}

2. Group 2 (13\% of respondents) - dominated by individuals who moved to, and live in, the area to have good public transport services. They are aware of environmental issues: $66 \%$ of them have heard about sustainable development. They have the lowest car ownership rates: some do not have a car at all. Forty percent of the group is less than 30 years old.

3. Group 3 (35\% of respondents) - dominated by individuals who moved into, and live in, the area to have a larger house and good access to parking. These people do not use their car much within the development, but their proportion of walkingdriving trips changes inline with the distance of an activity from home (the further they travel, the less they walk). Although they are concerned about environmental issues, only 57\% think that they need to change their behavior.

4. Group 4 (46\% of respondents) - dominated by individuals who moved to, and live in, the area to have a larger house and good access to parking Unlike Group 3, they use the car for 36\% of trips within the development, and his rises to $92 \%$ when traveling outside the development. They have the highest car ownership levels. Two thirds of them have heard about sustainable development and think they need to change.

5. Group 5 ( $0.3 \%$ of respondents) - although they have not heard of sustainable development, these individuals have higher proportions of walking and cycling trips than the other groups. This group has the highest number of walking trips.

Table 1 also shows that although almost all respondents were aware of environmental issues, their motivations for moving to these developments differ significantly. One might expect respondents to state that some of the sustainability features 
were important in their decisions to move, and indeed some, such as access to public transport, did feature. However, the majority of the respondents cited 'parking availability' and 'house size' as key drivers. This is perhaps counter to the idea of these developments being more 'sustainable' than developer norms, but demonstrates the divergence between planners' aspirations for these places and residents' perspectives. In terms of 'sustainable behaviors', some residents think that they may need to change their actions, whilst others do not. Nevertheless, almost all of them said that 'other people need to change'.

It seems there is an indication of self-selectivity, where individuals chose their residential locations partly based on their travel preferences (in similar findings to Handy et al. (2005)). But, it is also clear that the behavior is not only influenced by their preferences but also a result of compromising many factors.

\section{Needs, infrastructure and attitudes}

Although the previous sections have suggested some built environment impacts on travel behavior, the real relationships between factors are not straight forward. There are various other factors influencing trends, including individual sociodemographic factors and attitudes. To explore the impacts of built environment and individual attitudes to mode choice in a more comprehensive way, regression analysis is used. The respondents' socio-demographic and household characteristics are included in the analysis. Dummy variables of the neighborhoods' characteristics are also introduced to capture the local conditions for walking, cycling and using public transport. Whilst the datasets have very detailed information on the built environment features, to avoid an unmanageable set of variables, only the most significant in terms of policy and theory are included in these model estimations. The reference categories used in these analyses are: male, older than 40, household

Table 2

Percentage of walking as the main mode to reach the activity location.

\begin{tabular}{|c|c|c|c|}
\hline & $\begin{array}{l}\text { The location is located within the } \\
\text { respondents' development area }\end{array}$ & $\begin{array}{l}\text { The location is located nearby the } \\
\text { respondents' development area }\end{array}$ & $\begin{array}{l}\text { The location is located outside the } \\
\text { nearby development areas }\end{array}$ \\
\hline \multicolumn{4}{|l|}{ Constant } \\
\hline \multicolumn{4}{|l|}{ Female } \\
\hline \multicolumn{4}{|l|}{ Up to 30 years old } \\
\hline $\begin{array}{l}\text { Between } 31 \text { and } 40 \text { years } \\
\text { old }\end{array}$ & & 0.045 & $0.034^{* *}$ \\
\hline $\begin{array}{l}\text { Presence of dependent } \\
\text { children }\end{array}$ & 0.085 & & \\
\hline $\begin{array}{l}\text { Number of car within } \\
\text { household }\end{array}$ & & $-0.065^{*}$ & $-0.036^{*}$ \\
\hline Household size & & $0.025^{* *}$ & \\
\hline \multicolumn{4}{|l|}{$\begin{array}{l}\text { Have lived in the are more } \\
\text { than } 2 \text { years }\end{array}$} \\
\hline Low density development & & $-0.212^{* *}$ & \\
\hline High density development & $-0.311^{* *}$ & & \\
\hline Low mixed & & $0.262^{*}$ & $0.102^{* *}$ \\
\hline \multicolumn{4}{|l|}{ Highly mixed } \\
\hline \multicolumn{4}{|l|}{ Local integration } \\
\hline \multicolumn{4}{|l|}{ Global integration } \\
\hline \multicolumn{4}{|l|}{ Curvilinear street pattern } \\
\hline Culs-de-sac street pattern & $0.341^{* *}$ & & 0.129 \\
\hline \multicolumn{4}{|l|}{$\begin{array}{l}\text { Very good nature } \\
\text { surveillance }\end{array}$} \\
\hline Very good public realm & $0.348^{* *}$ & & \\
\hline \multicolumn{4}{|l|}{$\begin{array}{l}\text { Good/very good seating } \\
\text { and open space }\end{array}$} \\
\hline \multicolumn{4}{|l|}{ Good pedestrian crossing } \\
\hline \multicolumn{4}{|l|}{$\begin{array}{l}\text { No. of direct pedestrian } \\
\text { route links to outside }\end{array}$} \\
\hline $\begin{array}{l}\text { No. of streets with traffic } \\
\text { calming measures }\end{array}$ & $0.005^{* *}$ & & \\
\hline $\begin{array}{l}\text { Have an environmental } \\
\text { concern }\end{array}$ & $0.113^{* *}$ & $0.145^{*}$ & \\
\hline Believe that it is other fault & 0.096 & & \\
\hline \multicolumn{4}{|l|}{$\begin{array}{l}\text { Believe that he/she should } \\
\text { change }\end{array}$} \\
\hline Adjusted $R$-square & 0.059 & 0.179 & 0.077 \\
\hline
\end{tabular}

Note: Only main significant coefficients at least at 10\% level shown.

* Coefficient significant at $\alpha=1 \%$.

${ }^{* *}$ Coefficient significant at $\alpha=5 \%$. 
Table 3

Percentage of 'cycle' as the main mode to reach the activity location.

\begin{tabular}{|c|c|c|c|}
\hline & $\begin{array}{l}\text { The location is located within the } \\
\text { respondents' development area }\end{array}$ & $\begin{array}{l}\text { The location is located nearby the } \\
\text { respondents' development area }\end{array}$ & $\begin{array}{l}\text { The location is located outside the } \\
\text { nearby development areas }\end{array}$ \\
\hline Constant & & -0.207 & $-0.144^{* *}$ \\
\hline \multicolumn{4}{|l|}{ Female } \\
\hline \multicolumn{4}{|l|}{ Up to 30 years old } \\
\hline $\begin{array}{l}\text { Between } 31 \text { and } 40 \text { years } \\
\text { old }\end{array}$ & & & 0.014 \\
\hline \multicolumn{4}{|l|}{$\begin{array}{l}\text { Presence of dependent } \\
\text { children }\end{array}$} \\
\hline $\begin{array}{l}\text { Number of car within } \\
\text { household }\end{array}$ & & & $-0.009^{* *}$ \\
\hline \multicolumn{4}{|l|}{ Household size } \\
\hline \multicolumn{4}{|l|}{$\begin{array}{l}\text { Have lived in the are } \\
\text { more than } 2 \text { years }\end{array}$} \\
\hline \multicolumn{4}{|l|}{$\begin{array}{l}\text { High density } \\
\text { development }\end{array}$} \\
\hline \multicolumn{4}{|l|}{ Low mixed } \\
\hline \multicolumn{4}{|l|}{ Highly mixed } \\
\hline \multicolumn{4}{|l|}{ Local integration } \\
\hline Global integration & & 0.214 & \\
\hline \multicolumn{4}{|l|}{ Curvilinear street pattern } \\
\hline \multicolumn{4}{|l|}{ Culs-de-sac street pattern } \\
\hline $\begin{array}{l}\text { Very good nature } \\
\text { surveillance }\end{array}$ & 0.195 & $0.210^{* *}$ & \\
\hline \multicolumn{4}{|l|}{ Very good public realm } \\
\hline $\begin{array}{l}\text { Secured bike store in } \\
\text { public space }\end{array}$ & $0.078^{* *}$ & $0.141^{*}$ & $0.066^{*}$ \\
\hline \multicolumn{4}{|l|}{ Very good cycle path } \\
\hline \multicolumn{4}{|l|}{ No. of direct cycle paths } \\
\hline \multicolumn{4}{|l|}{$\begin{array}{l}\text { No. of streets with traffic } \\
\text { calming measures }\end{array}$} \\
\hline $\begin{array}{l}\text { Have an environmental } \\
\text { concern }\end{array}$ & $0.042^{* *}$ & 0.035 & \\
\hline \multicolumn{4}{|l|}{$\begin{array}{l}\text { Believe that it is other } \\
\text { fault }\end{array}$} \\
\hline \multicolumn{4}{|l|}{$\begin{array}{l}\text { Believe that he/she } \\
\text { should change }\end{array}$} \\
\hline Adjusted $R$-square & 0.006 & 0.159 & 0.072 \\
\hline
\end{tabular}

Note: Only main significant coefficients at least at $10 \%$ level shown.

* Coefficient significant at $\alpha=1 \%$.

${ }^{* *}$ Coefficient significant at $\alpha=5 \%$.

without dependent children, medium density development, medium mixed and distorted grid street pattern and no discernible street pattern.

\subsection{Factors encouraging residents to walk more}

Table 2 shows the estimation results of linear regression for the proportion of walk trips as residents' main travel mode. The dependent variables are the percentage of walk trips in reaching in the activity location - either it is located within, nearby or outside the respondents' development. The results show that:

- Individuals aged between 31 and 40 walk more to activity locations nearby and outside their development area than others.

- Individuals with dependent children walk more in their neighborhood compared with their counterparts. Whilst larger household sizes increase the probability of an individual walking more to activity locations nearby their development area, the availability of a private car significantly reduces the number of longer walk trips.

- Counter to expectations, high density development is associated with fewer walking trips within the neighborhood. Lower housing densities are associated with fewer walking trips to nearby locations.

- A lower mix of development ${ }^{1}$ is associated with more walking trips to locations nearby and outside the development, but there are no significant relationships between mix and walking within the development.

\footnotetext{
${ }^{1}$ Low mixed development is an area with four or less activity locations, such as school, stores and health services, within $0.5-1 \mathrm{~km}$ walk from the home location. It is defined as highly mixed if there are more then six activity locations from home locations within $0.5-1 \mathrm{~km}$ walk.
} 
- Culs-de-sac street patterns are marginally associated with more walking trips within and outside the neighborhood. This is counter to urban design theory that assumes higher walking levels in more permeable layouts. However, this result could be explained by the fact that the developments with culs-de-sac in this study also have other walking-friendly features.

- Good quality public realm and the presence of traffic calming measures increase the proportion of walking trips within the neighborhood.

- Environmental concern is a significant factor in encouraging individuals to walk within and nearby their neighborhoods, but not to locations outside their development. A belief that others should change also has a marginal influence on the amount of walk trips an individual makes within their neighborhood, but not the self motivation that he/she should change.

\subsection{Factors encouraging residents to cycle more}

The estimation results (Table 3) show only a few significant influences on the proportion of cycle trips, although this result must be treated with caution because of the small number of respondents who reported that they cycle. They show that:

- Residents aged between 31 and 40 cycle more to locations outside the development area than others.

- Car availability reduces the number of cycling trips outside the development area.

- Low densities are associated with increases in the number of cycle trips within the neighborhood.

- Better connections between the neighborhood and the rest of the area encourages individuals to cycle more to their nearby areas.

Table 4

Percentage of 'public transport' as the main mode to reach the activity location.

\begin{tabular}{|c|c|c|c|}
\hline & $\begin{array}{l}\text { The location is located within the } \\
\text { respondents' development area }\end{array}$ & $\begin{array}{l}\text { The location is located nearby the } \\
\text { respondents' development area }\end{array}$ & $\begin{array}{l}\text { The location is located outside the } \\
\text { nearby development areas }\end{array}$ \\
\hline Constant & & & 0.368 \\
\hline Female & & & 0.035 \\
\hline \multicolumn{4}{|l|}{ Up to 30 years old } \\
\hline $\begin{array}{l}\text { Between } 31 \text { and } 40 \text { years } \\
\text { old }\end{array}$ & & & -0.041 \\
\hline \multicolumn{4}{|l|}{$\begin{array}{l}\text { Presence of dependent } \\
\text { children }\end{array}$} \\
\hline $\begin{array}{l}\text { Number of car within } \\
\text { household }\end{array}$ & $-0.057^{*}$ & $-0.092^{*}$ & $-0.126^{*}$ \\
\hline Household size & $0.017^{* *}$ & $0.023^{* *}$ & 0.020 \\
\hline $\begin{array}{l}\text { Have lived in the are more } \\
\text { than } 2 \text { years }\end{array}$ & & & $-0.076^{*}$ \\
\hline Low density development & & -0.261 & \\
\hline High density development & & $0.306^{*}$ & \\
\hline Low mixed & & $-0.379^{* *}$ & \\
\hline \multicolumn{4}{|l|}{ Highly mixed } \\
\hline \multicolumn{4}{|l|}{ Local integration } \\
\hline \multicolumn{4}{|l|}{ Global integration } \\
\hline \multicolumn{4}{|l|}{ Curvilinear street pattern } \\
\hline Culs-de-sac street pattern & & 0.284 & \\
\hline \multicolumn{4}{|l|}{$\begin{array}{l}\text { No. of bus routes through } \\
\text { development }\end{array}$} \\
\hline $\begin{array}{l}\text { Distance to nearest bus stop } \\
\text { from center of dev. }\end{array}$ & & $-0.001^{* *}$ & \\
\hline $\begin{array}{l}\text { Distance to nearest train } \\
\text { station }\end{array}$ & & $-0.00004^{*}$ & \\
\hline $\begin{array}{l}\text { Distance to nearest bus } \\
\text { station }\end{array}$ & & $0.00006^{*}$ & 0.00005 \\
\hline \multicolumn{4}{|l|}{ No. of direct pedestrian } \\
\hline \multicolumn{4}{|l|}{$\begin{array}{l}\text { No. of streets with traffic } \\
\text { calming measures }\end{array}$} \\
\hline \multicolumn{4}{|l|}{$\begin{array}{l}\text { Have an environmental } \\
\text { concern }\end{array}$} \\
\hline \multicolumn{4}{|l|}{ Believe that it is other fault } \\
\hline \multicolumn{4}{|l|}{$\begin{array}{l}\text { Believe that he/she should } \\
\text { change }\end{array}$} \\
\hline Adjusted $R$-square & 0.191 & 0.377 & 0.382 \\
\hline
\end{tabular}

Note: Only main significant coefficients at least at $10 \%$ level shown.

${ }^{*}$ Coefficient significant at $\alpha=1 \%$.

** Coefficient significant at $\alpha=5 \%$. 
- Secured bike storage plays a crucial role in increasing individual cycle trips in all areas.

- Good natural surveillance also increases the proportion of cycle trips within and near the neighborhoods.

- Individual concern about the environment increases the amount of cycle trips within the neighborhood, and also marginally to the nearby areas.

\subsection{Factors encouraging residents to use public transport}

Table 4 shows results of the impacts of individual socio-demographic and built environment factors on the percentage of public transport trips. Compared with the walking and cycling trip proportion models, the public transport trip proportion models have much higher 'goodness of fit' ( $R$-square) (this could be due to the low numbers of cyclists).

The estimation results show that:

- Car availability is the main factor that reduces the proportion of public transport trips significantly.

- Distance to the nearest bus station encourages individuals to use public transport, especially to go to nearby locations.

- Larger household size is associated with more public transport trips. Perhaps this is because householders have to share access to the car (if any) with other household members.

- Individual environmental concerns do not have any significant influence on the proportion of individual public transport trips.

\section{Conclusions}

The analysis found that, although the developments aimed, to varying degrees, to promote sustainable lifestyles, this had not been a primary motivation for most residents to move to them. Some sustainability features had been factors in their choices, but the majority of the respondents moved to gain extra house space and in many instances extra parking space. Some of the residents were in social housing so in essence were not 'choosing' the move in the same way as those purchasing their homes in the private market. The analysis, however, shows that, overall, residents moving into these schemes demonstrated similar motivations to those moving into any new housing, i.e. more space and a good location. Overall, the developments attracted a high proportion of individuals in higher socio-economic groups who want to own and use cars, but also value proximity to public transport.

In terms of attitudes toward the environment and environmental behaviors, almost all respondents were aware of environmental issues, but their views did not necessarily 'match' their travel behavior. Some think that they may need to change their behavior to become more sustainable, whilst others do not. Nevertheless, almost all respondents felt that other people needed to change their behaviors to ensure a sustainable future. Individuals' environmental concerns only had a strong relationship with walking within and nearby the neighborhood. The relationship is limited with cycling behavior and there is no evidence of such an influence on public transport travel or walking and cycling to locations outside the neighborhood.

A number of other characteristics of the residents were also tested for their influence on travel behavior, including mode choice. In line with previous studies, residents' car availability was a significant influence: it is the main factor that discourages public transport trips, but also reduces walking and cycling. There are also variations in travel patterns for different household types and ages. Couples with dependent children and retired couples with no dependent children use the car most for trips nearby and outside the developments, and retired couples also drive the most within the developments. Those aged 31-40 are more likely to walk to places near their neighborhood than other age groups, and they also are more likely to cycle outside the development.

The influence of urban design features on travel behaviors was mixed. Some of the relationships found in previous studies, such as higher incidences of walking in denser, mixed and more permeable developments were not born out. In fact higher densities were associated with fewer walking trips within the neighborhood and mix of use did not have a significant relationship. Likewise residents of these developments owned more cars than the population as a whole. However, the specific scale and nature of the developments and characteristics of the residents need to be considered when interpreting these findings. Sustainable modes of travel were found to be related to some urban design features: secured bike storage, high connectivity of the neighborhoods to the nearby area, natural surveillance, high quality public realm and traffic calming all proved significant. Likewise the provision of facilities within and nearby the development encouraged far high levels of walking.

\section{Acknowledgments}

The research reported is from 'The Sustainable Lifestyles Project: The contribution of 'sustainable' new developments to sustainable lifestyles, an evaluation of schemes in the UK'. It was funded by the Engineering and Physical Sciences Research Council, under the Sustainable Urban Environments Programme, as part of the City Form consortium. The previous version of this paper was presented at the 89th Annual Meeting of the Transportation Research Board, Washington, DC, 2010. 


\section{References}

Barton, H., Grant, M., Guise, R., 2003. Shaping Neighborhoods for Health and Sustainability. Spon, London.

Department of the Environment Transport and the Regions, 1998. Places, Streets and Movement: a Companion Guide to Design Bulletin 32: Residential Roads and Footpaths, Department of the Environment Transport and the Regions. DETR, London.

Department of the Environment Transport and the Regions, 2000. By Design: Urban Design in the Planning System: Towards Better Practice DETR. Thomas Telford Publishing, London.

Department of the Environment Transport and the Regions and the Commission for Architecture and the Built Environment, 2000. By Design: Urban Design in the Planning System: Towards Better Practice, DETR, CABE. Thomas Telford Publishing, London.

Handy, S., Cao, X., Mokhtarian, P., 2005. Correlation or causality between the built environment and travel behavior? Evidence from Northern California. Transportation Research Part D 10, 427-444.

Handy, S.L., Clifton, K.J., 2001. Local shopping as a strategy for reducing automobile travel. Transportation 28, 317-346.

Hickman, R., Banister, D., 2005. Reducing Travel by Design, in Williams, K. (Ed.), Sustainable Planning, Urban Form and Sustainable Transport, Ashgate.

Susilo, Y.O., Dijst, M., 2009. How far is too far? Travel time ratios for activity participations in the Netherlands. Transportation Research Record 2134, 89-98.

Susilo, Y.O., Hanks, N., Ullah, M., 2011. An Exploration of Shoppers Travel Mode Choice in Visiting Convenience Stores in the United Kingdom. The 90th Transportation Research Board Annual Meeting, Washington, DC.

Susilo, Y.O., Waygood, E.O.D., 2012. The structural changes of children's activity-travel engagements in the Osaka Metropolitan Area. The Journal of Transport Geography 20, 41-50.

Williams, K., Dair, C., 2007. A framework for assessing the sustainability of brownfield developments. Journal of Environmental Planning and Management $50,23-40$.

Williams, K., Dair, C., Lindsay, M., 2009. Neighborhood design and sustainable lifestyles. In: Jones, C., Jenks, M. (Eds.), Dimensions of the Sustainable City. Springer.

Williams, K., Jenkins, M., Burton, E., 2000. Achieving Sustainable Urban Form. E and FN Spon, London. 